Author: JD van der Vyver

THE RIGHT TO SELF-DETERMINATION OF CULTURAL, RELIGIOUS AND LINGUISTIC COMMUNITIES IN SOUTH AFRICA

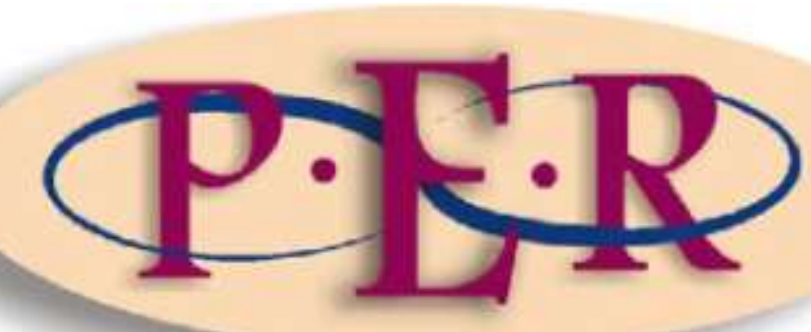

2011 VOLUME 14 No 4

http://dx.doi.org/10.4314/peli.v14i4.1 


\section{THE RIGHT TO SELF-DETERMINATION OF CULTURAL, RELIGIOUS AND LINGUISTIC COMMUNITIES IN SOUTH AFRICA}

JD van der Vyver*

The South African nation comprises perhaps the most diverse plural composition in the entire world and is furthermore known for the polarization of factions of the population. ${ }^{1}$ This raises the question how to bring about and to maintain the peaceful co-existence of the cultural, religious and linguistic varieties within its fold. Several models to cope with group-related tensions within a political community have been put to the test in different countries of our troublesome times. Nepal is a most recent case in point.

Earlier this month, on 5 to 7 May 2011, I was one of eleven "international experts" from abroad that were invited to Kathmandu to address problems encountered by the Constitutional Assembly of that country in the drafting of a new constitution. Since its creation in 1768 as a unified State, Nepal was a monarchy. Its first true and meaningful constitution was adopted in 1990. That Constitution formally recognized royal powers within a constitutional monarchy and proclaimed the country to be a Hindu Sate. Dissatisfaction with the constitution prompted a Maoist insurgency which plunged the country into a decade-long civil war that brought about approximately 17 500 casualties. A twelve-point peace agreement was concluded in 2005. An interim Constitution was put in place and the King was forced to abdicate in 2008 (he is now an ordinary citizen of the country and his palace was converted into a museum). The first president, Dr Ram Baran Yadav, was sworn in on 23 July 2008 under the current interim constitution. A major cause of unrest in Nepal was its diverse ethnic and religious population. Although the vast majority of Nepali are Hindu's, there are influential Buddhist and Muslim minorities, and the ethnic composition of the

\footnotetext{
* JD van der Vyver. BComm, LLB, Honns BA (PU for CHE) LLD (Pret). IT Cohen Professor of International Law and Human Rights, Emory University School of Law; Extraordinary Professor in the Department of Private Law, University of Pretoria (JVAND02@emory.edu).

See S v Makwanyane 19953 SA 391 (CC) para 308 (Mokgoro J referring to South Africans having "a history of deep division characterised by strife and conflict"); Du Toit $v$ Minister for Safety and Security 20096 SA 128 (CC) para 17 (Lange CJ stating: "The South African nation was for decades a deeply divided society characterised by gross violations of fundamental human rights").
} 
population reflects no less than 91 different language groups. One of the issues the "international experts" were asked to address was a proposal - one with wide support among politicians - to apply a federal system of government, based on the ethnic composition of the Nepalese population, as a means of securing internal peace in the years to come. We cautioned against that proposed "solution". Complete territorial segregation of ethnic varieties in any political community is almost impossible to orchestrate; and consinging regional powers of government to cultural, religious or linguistic factions could be a recipe for disaster. We know from the gruesome experiences in the former Yugoslavia that attempts to create religiously or ethic homogenous states could lead to profound animosity toward the other in one's midst, and might culminate in a policy of "ethnic cleansing" that could include brutal acts of genocide.

The territorial seclusion and political empowerment of ethnic groups are of course not confined to Nepal. Orthodox Judaism also favours segregation of conflicting groups within a particular political domain. Orthodox Judaism does not believe in turning the other cheek - a decree to do so comes from the New Testament; instead, the Talmud proclaims that in order to maintain peace, one must construct a fence to separate those who belong from their enemies.

There are also attempts in place to deal with potential group related conflicts in a political society by promoting homogeneity. Within the European community, France, Greece and Turkey can be singled out as countries not favourably disposed to accommodating group-related alliances or practices within their respective borders. Article 15(3)(c) of the Nigerian Constitution placed an obligation on the State to encourage inter-marriages between members of different religious, ethnic or linguistic communities for the purpose of "promoting national integration." ${ }^{2}$ The truth of the matter is, though, that the Nigerian people are as divided today as it ever was - or perhaps even more so.

The new South Africa abandoned territorial segregation as a supposed recipe for peaceful co-existence of racial and ethnic groups, and also did not attempt to

2 Article 15(3)(c) Constitution of the Federal Republic of Nigeria (1999). 
promote homogeneity of our nation. It instead proposed to promote national unity by totally different means. Its constitution encourages the maintenance of, and pride in, one's ethnic, religious and linguistic group identities. The constitutional preamble thus expresses the belief that all who live in South Africa are "united by our diversity." ${ }^{3}$ In its substantive provisions, it proclaims eleven official languages, ${ }^{4}$ calls on the State "to take practical and positive measures to elevate the status and advance the use of ... [indigenous languages of our people]", 5 and affords to everyone "the right to use the language and to participate in the cultural life of their choice."6 The Constitution accordingly guarantees the right to self-determination of cultural, religious and linguistic communities in accordance with international directives that apply in this regard. ${ }^{7}$

\section{The right to self-determination: historical perspective}

In the early phases of the $20^{\text {th }}$ Century, proponents of socialism were confronted with a challenging problem. According to the teachings of Karl Marx and Friedrich Engels the entire world will in due course be subjected, through a revolution of the proletariat, to a particular economic dispensation known as communism. Subjection of the entire world community to this economic dispensation will not be negotiable, but what would be the status of nation states within the over-arching and universal structures of communism? In 1913 Joseph Stalin (1879-1953) published a treatise on Marxism and the National Question, followed in 1916 by the more elaborate Thesis on the Socialist Revolution and the Right of Nations to Self-Determination of Lenin (1870-1924). Both authors proclaimed that nation states will retain the right to self-determination. According to Antonio Cassese, Lenin's Thesis on the Socialist Revolution constituted "the first compelling enunciation of the principle" of selfdetermination of peoples at the international level. ${ }^{8}$

The special prominence of the right to self-determination in international law has been attributed to the American President, Woodrow Wilson (1856-1924). Robert

\footnotetext{
Preamble Constitution of the Republic of South Africa, 1996. Section 8(1) Constitution of the Republic of South Africa, 1996.

Section 8(2) Constitution of the Republic of South Africa, 1996.

Section 30 Constitution of the Republic of South Africa, 1996.

Section 31, 235 Constitution of the Republic of South Africa, 1996.

Cassese Self-determination 15.
} 
Friedlander thus accredited President Wilson's Fourteen Points Address of 8 January 1918 as "transforming self-determination into a universal right." ${ }^{9}$ President Wilson included in those Fourteen Points one that proclaimed:

[a] free, open-minded, and absolutely impartial adjustment of all colonial claims, based upon a strict observance of the principle that in determining all such questions of sovereignty the interests of the population concerned must have equal weight with the equitable claims of government whose title is to be determined. ${ }^{10}$

In the Fourteen Point Address, President Wilson never really used the word "selfdetermination". It only became part of his vocabulary in an address to a joint session of the two Houses of Congress delivered on 11 February 1918 when he proclaimed:

National aspirations must be accepted; peoples may now be dominated and governed only by their own consent. "Self-determination" is not a mere phrase. It is an imperative principle of action, which statesmen will henceforth ignore at their peril. ${ }^{11}$

The above citation from the Fourteen Point Address has come to be regarded as the basis of the League of Nations policy for dealing with the future dispensation of nation states that were part of the world empires defeated and dissolved through World War I. ${ }^{12}$ The right to self-determination of those nation states were conditioned by the so-called mandate system of the League of Nations under which the conquered nations were to be prepared by a designated mandatory state for political independence, or in the case of South-West Africa (Namibia) for eventual incorporation into the Union of South Africa as a fifth province of that country. ${ }^{13}$

Friedlander 1975 Detroit Col L Rev 71, 73.

Wilson "Fourteen Points Address" point 5.

Wilson "War Aims" para 12 (11 Feb 1918), Messages and Papers of the President vol XVIII 8447 8450. See also the address of President Wilson delivered in Baltimore, Maryland on 6 April 1918 on the occasion of the first anniversary of America's participation in the European War and the third inauguration of the Third Liberty Loan, where he referred to "our ideals, the ideals of justice and humanity and liberty, the principle of free self-determination of nations, upon which all the modern world insists...". Van Dyke Human Rights 86.

13 The mandate system was the brainchild of Jan Christian Smuts (1870-1950) of South Africa, a General in the Anglo-Boer War (1899-1902) and a Cambridge graduate, who was invited by Great Britain to be part of its delegation to the Paris Peace Conference where the Peace Treaty of Versailles (1919) was drafted. Smuts in December 1918 outlined the mandate system in a League of Nations plan under the heading of "A Practical Suggestion", which was thereupon included by President Woodrow Wilson in his second draft of the League of Nations Covenant. 
In its infancy, when World War I was drawing to a close, the idea of "selfdetermination" was therefore advanced to legitimise the disintegration of the Ottoman, German, Russian and Austro-Hungarian empires, ${ }^{14}$ and within that context vested in "ethnic communities, nations or nationalities primarily defined by language or culture" whose right to disrupt existing states derived justification from its substantive directive: ${ }^{15}$ self-determination here denoted the right of "peoples" in the sense of (territorially defined) nations to political independence. ${ }^{16}$

But this was not where it all would end. The concept over time acquired different shades of meaning, depending in each instance on the nature and disposition of the peoples claiming that right. ${ }^{17}$

Following World War II, the emphasis of the concept of self-determination shifted to the principle "of bringing all colonial situations to a speedy end": ${ }^{18}$ the repositories of the concerned right in this sense were colonized peoples, and the substance of their right denoted political independence "of peoples that do not govern themselves,

14 Cassese International Law para 80 (131-34); Emerson 1971 AJIL 463; Friedlander Detroit Col L Rev 71.

15 Berman 1998 Wisc Int'l LJ 86-87.

16 It should be noted, though, that even then secession from existing empires was not a right in itself. In the advisory opinion of the International Committee of Jurists in the Aaland Island Case it was pointed out that "the right of disposing of national territory" was essentially an attribute of sovereignty and that "Positive International Law does not recognize the right of national groups, as such, to separate themselves from the State of which they form part by the simple expression of a wish, any more than it recognizes the right of other States to claim such a separation." "Report of the International Committee of Jurists entrusted by the Council of the League of Nations with the task of giving an advisory opinion upon the legal aspects of the Aaland Islands question" (Aaland Islands Question 1920 League of Nations Official Journal (Supp 3)). It was only when "the formation, transformation and dismemberment of States as a result of revolutions and wars create situations of fact which, to a large extent, cannot be met by applying the normal rules of positive law" that "peoples" may either decide to form an independent state or choose between two existing ones. (Aaland Islands Question 1920 League of Nations Official Journal (Supp 3) 6). In such circumstances, when sovereignty has been disrupted, "the principle of selfdetermination of peoples may be called into play": new aspirations of certain sections of a nation, which are sometimes based on old traditions or on a common language and civilization, may surface and produce effects which must be taken into account in the interests of the internal and external peace of nations.

17 Van der Vyver 1991a Emory Int'l L Rev 395-416; Van der Vyver $2000 \mathrm{~J}$ Transnat'l L \& Pol'y 1419; Van der Vyver "Self-determination" 258-61; Van der Vyver 2003 Stell L Rev 53-56, 58.

18 Western Sahara (Advisory Opinion of 22 May 1975) 1975 ICJ 1 31; and see also Legal Consequences for States of the Continued Presence of South Africa in Namibia (South West Africa) Notwithstanding Security Council Resolution 276 (1970) (Advisory Opinion of 21 June 1971) 1971 ICJ 1631 (the Court holding that the right to self-determination was applicable to "territories under colonial rule" and that it "embraces all peoples and territories which 'have not yet attained independence'"). 
particularly peoples dominated by geographical distant colonial powers." ${ }^{19}$

In the 1960's, yet another category of "peoples" came to be identified as repositories of a right to self-determination, namely those subject to racist regimes, and here the concept substantively signified the right of such peoples to participate in the structures of government within the countries to which they belong: ${ }^{20}$ the "self" in self-determination was no longer perceived to be territorially defined sections of the population in multinational empires, and did not merely comprise peoples under colonial rule or foreign domination, but also came to be identified with the entire community of a territory where the social, economic, and constitutional system was structured on institutionally sanctioned racial discrimination. ${ }^{21}$

Finally, the right to self-determination has been extended to national or ethnic, religious and linguistic minorities within a political community whose particular entitlements were centred upon a right to regulate their lives according to the traditions and customs of the concerned group. It is this final meaning of a right to self-determination that has come to be accepted by South Africa as a means for addressing sectional interests within the body politic.

19 Berman 1998 Wisc Int'l LJ 54. See also Cassese International Law para 43 (76); Van Dyke Human Rights 87; Berat 1990 Emory Int'l L Rev 283 (referring to self-determination and the equal right of peoples as "twin aspects of decolonization"); Emerson 1971 AJIL 463; Schachter "United Nations and Internal Conflict" 406-07; Tesfagiorgis 1987 Wisc Int'l LJ 78-80.

The linkage within the confines of the right to self-determination of systems of institutionalized racism and colonialism or foreign domination may be traced to the United Nations General Assembly's Declaration on the Inadmissibility of Intervention in the Domestic Affairs of States and the Protection of Their Independence and Sovereignty (1965), in which the United Nations demanded of all states to respect "the right to self-determination and independence of peoples and nations, to be freely exercised without any foreign pressure, and with absolute respect for human rights and fundamental freedoms," and to this end proclaimed that "all States shall contribute to the complete elimination of racial discrimination and colonialism in all its forms and manifestations.": Declaration on the Inadmissibility of Intervention in the Domestic Affairs of States and the Protection of Their Independence and Sovereignty (1965) para 6.

21 This development was probably prompted by the claim of South Africa that the establishment of independent tribal homelands as part of the apartheid policy constituted a manifestation of the right to self-determination of the different ethnic groups within the country's African population. Not so, responded the international community. The tribal homelands were a creation of the minority (white) regime and did not emerge from the wishes, or political self-determination, of the denationalized peoples themselves. 


\section{The right to self-determination of ethnic. religious and linguistic communities defined}

The right to self-determination of ethnic, religious and linguistic communities must not be confused with the comparable right of colonized countries or of peoples subject to a racist regime. In terms of the Covenant on Civil and Political Rights, selfdetermination of ethnic, religious and linguistic communities entails the following basic directive:

In those States in which ethnic, religious or linguistic minorities exist, persons belonging to such minorities shall not be denied the right, in community with the other members of their group, to enjoy their own culture, to profess and practice their own religion, or to use their own language. ${ }^{22}$

The Declaration on the Rights of Persons Belonging to National or Ethnic, Religious and Linguistic Minorities similarly speaks of:

the right [of national or ethnic, religious and linguistic minorities] to enjoy their own culture, to profess and practice their own religion, and to use their own language, in private and in public, freely and without interference or any form of discrimination. ${ }^{23}$

But there is more to self-determination of such communities. In virtue of the right to self-determination, governments, through their respective constitutional and legal systems, are required to secure the interests of distinct sections of the population that constitute minorities in the above sense. The Declaration on the Rights of Persons Belonging to National or Ethnic, Religious and Linguistic Minorities clearly spells out that obligation: protect, and encourage conditions for the promotion of, the concerned group identities of minorities under the jurisdiction of the duty-bound State; ${ }^{24}$ afford to minorities the special competence to participate effectively in decisions pertinent to the group to which they belong; ${ }^{25}$ do not discriminate in any

Article 27 Covenant on Civil and Political Rights (1966); and see in general Ermacora 1983-IV Recueil des Cours 246.

23 Article 2.1 Declaration on the Rights of Persons Belonging to National or Ethnic, Religious and Linguistic Minorities (1992).

24 Articles 1.1, 4.2 Declaration on the Rights of Persons Belonging to National or Ethnic, Religious and Linguistic Minorities (1992).

25 Article 2.3 Declaration on the Rights of Persons Belonging to National or Ethnic, Religious and Linguistic Minorities (1992). 
way against any person on basis of his/her group identity, ${ }^{26}$ and in fact take action to secure their equal treatment by and before the law. ${ }^{27}$ The Declaration further provides that:

States shall take measures to create favourable conditions to enable persons belonging to minorities to express their characteristics and to develop their culture, language, religion, traditions and customs, except where specific practices are in violation of national law and contrary to international standards. ${ }^{28}$

The Council of Europe's Framework Convention for the Protection of National Minorities specified minority rights in much the same vein: it guarantees equality before the law and equal protection of the laws; ${ }^{29}$ states parties promise to provide "the conditions necessary for persons belonging to national minorities to maintain and develop their culture, and to preserve the essential elements of their identity, namely their religion, language, traditions and cultural heritage"; 30 states parties recognize the right of persons belonging to a national minority "to manifest his or her religion or belief and to establish religious institutions, organizations and associations"; 31 and the Framework Convention guarantees the use of minority languages, in private and in public, orally and in writing. ${ }^{32}$

The South African Constitution is quite explicit in upholding these directives of international law. Section 31 provides:

(1) Persons belonging to a cultural, religious or linguistic community may not be denied the right, with other members of that community -

(a) to enjoy their culture, practise their religion and use their language; and

(b) to form, join and maintain cultural, religious and linguistic associations and other organs of civil society.

Article 3 Declaration on the Rights of Persons Belonging to National or Ethnic, Religious and Linguistic Minorities (1992).

27 Article 4.1 Declaration on the Rights of Persons Belonging to National or Ethnic, Religious and Linguistic Minorities (1992).

28 Article 4.2 Declaration on the Rights of Persons Belonging to National or Ethnic, Religious and Linguistic Minorities (1992).

29 Article 4.1 European Framework Convention for the Protection of National Minorities (1995).

30 Article 5.1 European Framework Convention for the Protection of National Minorities (1995).

Article 8 European Framework Convention for the Protection of National Minorities (1995).

Article 10.1 European Framework Convention for the Protection of National Minorities (1995); and see also the European Charter for Regional Minority Languages (1992). 
(2) The rights in subsection (1) may not be exercised in a manner inconsistent with any provision of the Bill of Rights. ${ }^{33}$

Drafters of the Constitution were also sensitive to the duty of the state to promote cultural, religious and linguistic diversity in South Africa. The Constitution thus makes provision for a Commission for the Promotion and Protection of the Rights of Cultural, Religious and Linguistic Communities; ${ }^{34}$ and it envisions the establishment, by means of national legislation, of a Pan South African Language Board charged, inter alia, with promoting and ensuring respect for "Arabic, Hebrew, Sanskrit and other languages used for religious purposes in South Africa." 35

It must be emphasized that the right of self-determination of ethnic, religious and linguistic groups (a) is not an unlimited right; and (b) does not include a right to political independence.

\subsection{Limitations of the right to self-determination}

The Declaration on the Rights of Persons Belonging to National or Ethnic, Religious and Linguistic Minorities excluded from the right to self-determination specific practices of an ethnic, religious or linguistic community that violate the national laws of a country and are contrary to international standards. ${ }^{36}$ It is submitted that the national-law limitation is to be conditioned by the international-standards criterion: it presupposes municipal regulation that remains within the confines of international standards and does not place undue restrictions upon the group interests of minorities.

Current state practice does not uphold the limitations inherent in the right to selfdetermination of ethnic, religious or religious communities dictated by the international standards criterion to the letter. For example, gender discrimination is condemned in almost all of the international human rights conventions and

Section 31 Constitution of the Republic of South Africa, 1996.

Section 181(1)(c), 185-86 Constitution of the Republic of South Africa, 1996; and see the Commission for the Promotion and Protection of the Rights of Cultural, Religious and Linguistic Communities Act 19 of 2002.

35 Section 6(5)(b)(ii) Constitution of the Republic of South Africa, 1996.

36 Article 4.2 Declaration on the Rights of Persons Belonging to National or Ethnic, Religious and Linguistic Minorities (1992). 
covenants, yet religious institutions that discriminate against women on gender grounds have thus far, successfully, claimed a sovereign right to conduct their affairs within the sphere of their internal household according to the dictates of their faith. And perhaps rightly so! Does one really want the state to compel the Roman Catholic Church, the Greek Orthodox Church, Orthodox Judaism, or the Gereformeerde Kerk (and others) to ordain women as priest or as part of their clergy?

Practices such as female genital mutilation (FGM), on the other hand, cannot be justified on basis of the right to self-determination of peoples. FGM amounts to sexually defined physical mutilation of extreme severity and with irreversible consequences, its practice is almost exclusively inspired by male interests (prolonged sexual pleasure of the male partner), it as such constitutes sex- and gender-based discrimination of the worst kind, and since it is mostly executed while the victim is an infant, it also implicates the rights of the child. The United Nations Declaration on the Elimination of Violence against Women (1993) mentions FGM as an instance of "violence against women". ${ }^{37}$

This raises the question as to an appropriate criterion for separating those violations of "international standards" that do, and those that do not, exceed the limits of the right to self-determination of ethnic, religious or linguistic communities. There are no clear answers to this question. It would seem, though, that those customs and traditions that threaten the life or violate the physical integrity of members of an ethnic, religious or linguistic group clearly exceed the permissible confines of the right to self-determination of the group.

Applying these norms in a South African setting is particularly problematic since cultural or ethnic traditions in many African communities include practices which are incompatible with the human rights ideology of our time and ought not to be tolerated.

37 Article 2(a) Declaration on the Elimination of Violence against Women (1993). 
The systems of human rights protection in the world today can, from a certain perspective, be divided into two main categories: those that have grown from the bottom up, and those that have been imposed from the top down. In countries belonging to the former category, the values embodied in a Bill of Rights were based upon, and kept track with, an existing and evolving public ethos. Drafters and lawcreating agencies simply endorsed moral perceptions entertained by a cross-section of the peoples comprising the nation. The American system of human rights protection may be cited as an example of this category.

South Africa, on the other hand, belongs to that category of political communities where Bill of Rights decrees have been imposed from the top down. That is to say, the rights and freedoms protected by the constitution have been dictated by internationally recognized norms of right and wrong, which are in many instances not in conformity with the moral perceptions and customary practices of large sections of the South African population. Some of the laws that have been drafted to implement the principles of human rights from time to time provoke strong voices of protest from groups within the country whose age-old customs may fall prey to the concerned legal reform measures. The lives they live and the customs they observe are in many instances far removed from the nice-sounding ideologies written into the constitution and specificities reflected in judgments of the courts. In one of the early judgments of the Constitutional Court, Justice Yvonne Mokgoro referred to the "delicate and complex" ${ }^{38}$ task of accommodating African customary law to the values embodied in the Bill of Rights, and noted that "[t]his harmonization will demand a great deal of judicious care and sensitivity." 39

Effective implementation of the human-rights-based laws and judgments within the entire country will in the final analysis be conditioned by the cultivation of a humanrights ethos as a stronghold of all peoples and in all tribal communities of the South African nation. In this respect South Africa still has many more miles to run.

\footnotetext{
$38 \quad$ Du Plessis v De Klerk 19965 SA 658 (CC).

39 Du Plessis v De Klerk 19965 SA 658 (CC).
} 


\subsection{Self-determination and a right to secession}

The failure of national systems to provide protection to sectional interests of peoples within their area of jurisdiction, or merely the perception of being marginalized, must be seen as an important contributing cause of the tireless aspirations toward the establishment of homogenous states for sections of the political community with a strong group consciousness: the Muslim community of Kashmir and in Kosovo, the Basques in Northern Spain, the Hindu factions in Sri Lanka, the Catholic minority in Northern Ireland, the Christian community in Southern Sudan, the Kurds in Iraq and Turkey, people of Macedonian extraction in Florina (Northern Greece), the peoples of Somaliland in Somalia, the northern provinces of Georgia, the Maoists in Nepal, and many others.

It must be emphasized, though, that the right of ethnic, religious and linguistic communities to self-determination does not include a right to secession; ${ }^{40}$ not even in instances where the powers that be act in breach of a minority's legitimate expectations. Three compelling arguments are decisive in this regard:

- The right to self-determination is almost invariably mentioned in conjunction with the territorial integrity of states, ${ }^{41}$ and reconciling the two principles in question necessarily means that self-determination must be taken to denote something less than secession.

- $\quad$ The right to self-determination vests in a people, while a new state created through secession is essentially territorially defined ${ }^{42}$ (it is a defined territory that secedes from an existing state and not a people); ${ }^{43}$

40 Van Dyke Human Rights 88; Berman 1998 Wisc Int'l LJ 87; Emerson 1971 AJIL 464-65.

41 See Final Act of the Conference on Security and Co-operation in Europe (1975), for example, a IV (territorial integrity) and a VIII (equal rights and self-determination of peoples).

42 According to Mosler "Subjects of International Law" 449: "States are constituted by a people, living in a territory and organized by a government which exercises territorial and personal jurisdiction." Doehring "State" defined a state in international law as "an entity having exclusive jurisdiction with regard to its territory and personal jurisdiction in view of its nationals." Dooyeweerd New Critique 414 defined the foundational function of a state in terms of "an internal monopolistic organization of the power of the sword over a particular cultural area within territorial boundaries." He further maintained that the leading or qualifying function of the state finds expression in a public legal relationship which unifies the government, the people and the territory constituting the political community into a politico-juridical whole. Dooyeweerd New Critique $433 f f$.

43 Dinstein 1976 ILQ 109 (noting that peoples seeking secession must be located in a well-defined territorial area in which it forms a majority). 
- The right to self-determination is a collective group right (entitlements included in that right can be exercised by individual members of the concerned group, either individually or collectively) while a right to secede is an institutional group right (where permissible, a decision to secede must be taken by a representative organ of the territorially defined group on behalf of the group as a whole).

General definitions of the right to self-determination, such as the one contained in the Declaration on the Granting of Independence to Colonial Countries and Peoples proclaiming the right of peoples to "freely determine their political status" and the right to "freely pursue their economic, social, and cultural development" ${ }^{44}$ should therefore not be seen as a general sanction of a right to political independence but must be limited and understood in the context of the subject-matter of the document from which they derive: peoples subject to colonial rule or foreign domination do have a right to political independence; ethnic, religious and linguistic minorities in an existing state do not. The definition of self-determination in international instruments including in that concept the right of peoples "freely [to] determine their political status and freely [to] pursue their economic, social and cultural development" ${ }^{45}$ was similarly not intended to undermine the rule of international law proclaiming the territorial integrity of states. The United Nations' 1993 World Conference on Human Rights said it all when the right of peoples to "freely determine their political status, and freely pursue their economic, social and cultural development" was expressly made conditional upon the following proviso:

This [definition of self-determination] shall not be construed as authorizing or encouraging any action which would dismember or impair, totally or in part, the territorial integrity or political unity of sovereign and independent States conducting themselves in compliance with the principles of equal rights and self-determination of peoples and thus possessed of a Government

44 Declaration on the Granting of Independence to Colonial Countries and Peoples (1960).

45 See a 1(1) Covenant on Economic, Social and Cultural Rights (1966); a 1(1) Covenant on Civil and Political Rights (1966); a 2 Declaration on the Granting of Independence to Colonial Countries and Peoples (1960). See also the first paragraph under the heading: "The Principle of Equal Rights and Self-Determination of Peoples" in the Declaration on Principles of International Law concerning Friendly Relations and Co-Operation among States in accordance with the Charter of the United Nations (1970); para 5 Declaration on the Inadmissibility of Intervention into the Domestic Affairs of States and the Protection of Their Independence and Sovereignty (1965); para VIII Final Act of the Conference on Security and Co-operation in Europe (1975). 
representing the whole people belonging to the territory without distinction of any kind. ${ }^{46}$

The United Nations Declaration on the Rights of Persons Belonging to National or Ethnic, Religious and Linguistic Minorities reiterated that its provisions must not be taken to contradict the principles of the United Nations pertaining to, inter alia, "sovereign equality, territorial integrity and political independence of States." 47 In the Framework Convention for the Protection of National Minorities, the Council of Europe also proclaimed:

Nothing in the present framework Convention shall be interpreted as implying any right to engage in any activity or perform any act contrary to the fundamental principles of international law and in particular of the sovereign equality, territorial integrity and political independence of States. ${ }^{48}$

The United Nations' Declaration on the Rights of Indigenous Peoples of 2007 also proclaims, somewhat inadvertently, that indigenous peoples are entitled to "freely determine their political status and freely pursue their economic, social and cultural development," ${ }^{49}$ but went on to emphasize that this entitlement must not be construed as "authorizing or encouraging any action that would dismember or impair, totally or in part, the territorial integrity or political unity of sovereign and independent States." 50

International law has been quite adamant in proclaiming the sanctity of post-World War II national borders, ${ }^{51}$ and in censuring attempts at secession in instances such

46 Article 1.2 Vienna Declaration and Programme of Action (1993).

47 Article 8.4 Declaration on the Rights of Persons Belonging to National or Ethnic, Religious and Linguistic Minorities (1992).

48 Article 21 European Framework Convention for the Protection of National Minorities (1995).

49 Declaration on the Rights of Indigenous Peoples (2007). The Declaration was adopted with only Australia, Canada, New Zealand and the United States opposing its adoption.

50 Article 46(1) Declaration on the Rights of Indigenous Peoples (2007).

51 Higgins Development of International Law 104-05; and see, for example, para III Final Act of the Conference on Security and Co-operation in Europe (1975). A III, para 3 Charter of the Organisation of African Unity (1963) committed member states to adhere to the principle of "respect for the sovereignty and territorial integrity of each State and for its inalienable right to independent existence." In furtherance of this principle, a resolution adopted by the Assembly of Heads of State and Government, held at Cairo in 1964, (Resolution adopted by the Assembly of Heads of State and Government, Cairo (1964)) called on all member states of the OAU "to respect the borders existing on their achievement of national independence." 
as Katanga, Biafra and the Turkish Republic of Northern Cyprus. ${ }^{52}$ As explained by Vernon van Dyke, "the United Nations would be in an extremely difficult position if it were to interpret the right to self-determination in such a way as to invite or justify attacks on the territorial integrity of its own members." 53

The Supreme Court of Canada in a judgment pertaining to the legality of cession from Canada of the province of Quebec - should a majority of the residents of that province through a referendum seek to effect the severance of that territory from Canada - summarized as follows the distinction between self-determination (referred to in the judgment as "internal self-determination") and secession (referred to in the judgment as "external self-determination"):

The recognized sources of international law establish that the right to selfdetermination of a people is normally fulfilled through internal selfdetermination - a people's pursuit of its political, economic, social and cultural development within the framework of an existing state. A right to external self-determination (which in this case potentially takes the form of a right to unilateral secession) arises in only the most extreme of cases, and then, under carefully defined circumstances. ${ }^{54}$

There are many compelling reasons why the destruction of existing political communities harbouring a plural society should be avoided at all costs:

- a multiplicity of economically non-viable states will further contribute to a decline of the living standards in the world community;

- $\quad$ the perception that people sharing a common language, culture or religion would necessarily also be politically compatible is clearly a myth, and disillusionment after the event might provoke profound resentment and further conflict;

- movement of people within plural societies across territorial divides has greatly destroyed ethnic, cultural or religious homogeneity in regions where it might have existed in earlier times, and consequently, demarcation of borders

52 See Van der Vyver 1991a Emory Int'I L Rev 403-07; and in greater detail, Crawford Creation of States 235-36 (Katanga) and 265 (Biafra); Dugard Recognition and the United Nations 86-90 (Katanga), 84-85 (Biafra) and 108-111 (Turkish Republic of Northern Cyprus); Van der Vyver 1991b Emory Int'I L Rev 35-37 (Katanga) and 42-44 (Turkish Republic of Northern Cyprus).

54 Reference Re Secession of Quebec 19982 SCR 217 para 126; and see Van der Vyver $2000 \mathrm{~J}$ Transnat'l L \& Pol'y 14-19. 
that would be inclusive of the sectional demography which secessionists seek to establish is in most cases quite impossible;

- affording political relevance to ethnic, cultural or religious affiliation not only carries within itself the potential of repression of minority groups within the nation, but also affords no political standing whatsoever to persons who, on account of mixed parentage or marriage, cannot be identified with any particular faction of the group-conscious community, or to those who - for whatever reason - do not wish to be identified under any particular ethnic, cultural or religious label;

- in consequence of the above, an ethnically, culturally or religiously defined state will more often than not create its own "minorities problem", which because of the ethnical, cultural or religious incentive for the establishment of the secession state - would almost invariable result in profound discrimination against those who do not belong, or worse still, a strategy of "ethnic cleansing".

Secession is indeed sanctioned by international law - not under the rubric of a right to self-determination but as a permissible political strategy in its own right. The restructuring of national borders is sanctioned by international law in two instances only:

(a) if a decision to secede is "freely determined by a people"55 - that is, a crosssection of the entire population of the state to be divided and not only inhabitants of the region wishing to secede; ${ }^{56}$ and

(b) if, following an armed conflict, national boundaries are redrawn as part of the peace treaty. ${ }^{57}$

55 Declaration on Principles of International Law concerning Friendly Relations and Co-Operation among States in accordance with the Charter of the United Nations (1970). The Declaration provides, under the heading: "The Principle of Equal Rights and Self-Determination of Peoples": "The establishment of a sovereign and independent State, the free association or integration with an independent State or the emergence into any other political status freely determined by a people constitute modes of implementing the right to self-determination by that people."

56 Heunis United Nations 328-30 lost sight of this truism when arguing that the establishment of the South African (racially defined) homeland states (the TBVC-countries) occurred in conformity with the right to self-determination. See also Booysen Volkereg 67. For a critical comment on the Heunis/Booysen argument, see Van der Vyver 1991b Emory Int'l L Rev 83 n 354. 
The reunification of Germany, the break-up of the Soviet Union, ${ }^{58}$ and parting of constitutional ways of the Czech Republic and Slovakia were in that sense "freely determined by the people,"59 while the secession of Eritrea from Ethiopia was sanctioned by a peace accord. The disintegration of the former Yugoslavia represents a complicated conglomeration of both principles. ${ }^{60}$ And I might add that the 2010 judgment of the International Court of Justice concerning The Unilateral Declaration of Independence in respect of Kosovo makes no sense at all. ${ }^{61}$

\section{$3 \quad$ Concluding observations}

Group rivalries are still rife in South Africa as a feature of the country's demographic divides. How to deal with such rivalries and the means of orchestrating reconciliation are central to social engineering within our troubled land.

Drafters of the South African Constitution rejected segregation of rival ethnic, religious and linguistic communities, as well as the promotion of cultural, religious or linguistic homogeneity within our nation, as a means of counteracting group-related tensions in the country's social construct. Instead, they opted for creating - in the celebrated words of Archbishop Desmond Tutu - "a rainbow people". The new constitutional dispensation accordingly seeks to promote pride in one's group

58 It should be specially noted that a 72 Konstitutsiya SSSR (USSR Constitution) 1977 expressly guaranteed the right of each Republic to secede from the Union.

59 Buchheit Secession 228-38 specified, as elements for legitimizing secession in any given case, that the section of a community seeking partition should possess a distinct group identity with reference to, for example, cultural, racial, linguistic, historical or religious considerations; those making a separatist claim must be capable of an independent existence, including economic viability (but bearing in mind international aid programs that might help a newly established political entity over its teething problems); and the secession must serve to promote general international harmony, or at least not be disruptive of international harmony or disrupt it more than the status quo is likely to do.

60 Article 1 Constitution of the Federal People's Republic of Yugoslavia (1946) authorised secession of its constituent republics; and see also para I of the Introductory Part (Basic Principles) Constitution of the Federal People's Republic of Yugoslavia (1963) (depicting Yugoslavia as "a federal republic of free and equal peoples and nationalities" united "on the basis of the right to self-determination, including the right of secession"); and see also art 1 Constitution of the Federal People's Republic of Yugoslavia (1963); para I of the Introductory Part (Basic Principles) Constitution of the Socialist Federal Republic of Yugoslavia (1974) (referring to "the right of every nation to self-determination" and "the brotherhood and unity of nations and nationalities"). However, the disintegration of the federation did not occur in accordance with the procedures prescribed for the exercise of the constitutional right to secession, and furthermore included territorial gains through conquest and ethnic cleansing.

61 Accordance with International Law of the Unilateral Declaration of Independence in respect of Kosovo ICJ General List No 141 (22 Jul 2010). 
identities: be proud of being an Afrikaner, or being a member of any of the rich variety of "peoples" within the African, Indian or coloured communities; be faithful to your membership of the Catholic, Methodist, Dutch Reformed, or Zion Christian Church, or as a member of the Muslim or Buddhist communities; find comfort in speaking the language of your cultural extraction, albeit Afrikaans, English, Greek, Portuguese, Tswana, Xhosa, or Zulu. Pluralism, tolerance and broadmindedness have been singled out by the European Court of Human Rights as indispensable components of a democratic society. ${ }^{62}$

Pride in your particular ethnic, religious or linguistic identity does not elevate one to a superior status in the community. Respect of others for your cultural values, religious persuasions or linguistic preferences demands of you to fully respect the culture, religion and language of others. The constitutional principle that applies in this regard has been reduced to perhaps the most basic moral directive for a "new South Africa"; one that finds expression in the concept of ubuntu or botho, "an idea based on deep respect for the [inner] humanity of another." ${ }^{163}$ Ubuntu translates into "humaneness" and constitutes "part of our rainbow heritage."64 It stands in sharp contrast to "dehumanising and degrading the individual."65 Justice Albie Sachs on occasion referred to ubunthu-batho in the sense of "civility" as "a precondition for the good functioning of contemporary democratic societies" and noted that "[c]ivility in a constitutional sense involves more than just courtesy and good manners. ... It .presupposes tolerance for those with whom one disagrees and respect for the dignity of those with whom one is in dispute."66

The constitution therefore subjects freedom of expression to limitations, which limitations include "advocacy of hatred that is based on race, ethnicity, gender or religion, and that constitutes incitement to cause harm." ${ }^{167}$ Under the Promotion of Equality and Prevention of Unfair Discrimination Act "no person may publish,

\footnotetext{
62 Handyside $v$ The United Kingdom 19761 EHRRR 737 754; and see Islamic Unity Convention v Independent Broadcasting Authority 20024 SA 295 (CC) para 28.

63 Dikoko v Mokhatla 20066 SA 235 (CC) paras 68, 69.

$64 S$ v Makwanyane 19953 SA 391 (CC) para 308 (per Mokgoro J).

$65 S$ v Makwanyane 19953 SA 391 (CC) para 250 (per Lange J).

66 Masetlha $v$ President of the RSA 20081 SA 566 (CC) para 238.

67 Section 16(2)(c) Constitution of the Republic of South Africa, 1996.
} 
propagate, advocate or communicate words ... against any person, that could reasonably be construed to demonstrate a clear intention to (a) be hurtful; (b) be harmful or to incite harm; (c) promote or propagate hatred."68 It is important to emphasize that South African law does not uphold the almost incontestable sanctity of freedom of speech, as does the American constitutional system. In South African law, "certain expressions do not deserve constitutional protection because it has the potential to impinge adversely on the dignity of others and cause harm". ${ }^{69}$ In South Africa, "the right to freedom of expression is not a pre-eminent freedom ranking above all others"; ${ }^{70}$ it in this respect "differs fundamentally from the balance struck in the United States," 71 where freedom of speech constitutes the basic norm - a Grundnorm - of the entire rights regime. ${ }^{72}$

The "new South Africa" is instead founded on zero tolerance for words and conduct that are offensive to others. Depicting members of a particular population groups as "hotnot", "kaffir" "rooinek" "boer", or "coolie" is therefore strictly forbidden since such names "have for decades been used to bring people of different races into contempt." ${ }^{73}$ Refusing to serve a Muslim client wearing a fez in a business enterprise open to the public constitutes unbecoming discrimination based on religion. ${ }^{74}$ The media are under legal constraint not to publish cartoons depicting the Prophet Mohammed as a terrorist (the ones that first appeared in a Danish newspaper), because they "advocate hatred and stereotyping of Muslims." ${ }^{75}$ A newspaper report that likens homosexuality with bestiality cannot be tolerated under freedom of the press demands because it promotes hatred against the gay and lesbian communities. $^{76}$

\footnotetext{
Section 10(1) Promotion of Equality and Prevention of Unfair Discrimination Act 4 of 2000.

Du Toit v Minister for Safety and Security 20096 SA 128 (CC) para 32.

$S$ v Mamabolo (E TV 7 others Intervening) 20013 SA 409 (CC) para 41.

$S$ v Mamabolo (E TV 7 others Intervening) 20013 SA 409 (CC) para 40.

72 Van der Vyver Constitutional Protection of Children 282; Van der Vyver 2005 Emory Int'l L Rev 508.

73 P Johnson v 94.7 Highveld Stereo Case No 07/2002 Broadcasting Complaints Commission (14 Feb 2002).

74 Woodways CC v Moosa Vallie Case No A251/05 (HC Western Cape) (31 Aug 2009).

75 Jamait-UI-Ulama of Transvaal $v$ Johncom Media Investment Ltd 1127/06 2006 ZAGPHC 12 (3 Feb 2006).

76 In South African Human Rights Commission v Jon Qwulane Case No 44/EQ JHB (31 May 2011) the Equality Court at the Johannesburg Magistrate's Court demanded an unqualified public apology to the gay and lesbian community from, and imposed a fine of R 100000 to be paid by,
} 
The chanting a so-called "freedom song" that includes the phrase dibulu iBhunu (shoot the boer) clearly, and without even a shadow of doubt, violates the proscription of offensive language. In a provisional decision, pending a final judgment by the Equality Court, Judge Bertelsmann held that "the offending words constitute hate speech, for which there is neither justification, nor protection in the Constitution"77 Dealing with the same matter in the Gauteng High Court, Acting Judge Halgryn held that the phrase dibulu iBhunu prima facie satisfies the requirements of the crime of incitement to commit murder. ${ }^{78}$

The Acting Judge was wrong, of course. "Shoot the Boer" prima facie amounts to incitement to commit genocide. And just for the record, changing the phrase to "Kiss the Boer" will make no difference in this regard. Incitement to commit genocide is often coached in euphemisms. ${ }^{79}$ Jurisprudence of the International Criminal Tribunal for Rwanda (ICTR) is particularly instructive in this regard. In Prosecutor $v$ Kambanda, for example, the accused pleaded guilty to incitement to commit genocide based on the following statement: you refuse to give your blood to your country and the dogs drink it for nothing. ${ }^{80}$ South African audiences know perfectly well that "kiss the boer" is a substitute for "shoot the boer".

As noted by Chief Justice Langa a while ago, "The process of reconciliation is an ongoing one which requires give and take from all sides." 81 "Our democracy is still fragile," said Judge Bertelsmann, adding that "Participants in the political and sociopolitical discourse must remain sensitive to the feelings and perceptions of other

Jon Qwulane (currently the South African ambassador in Uganda) for a newspaper article he wrote under the heading "Call me names, but gay is NOT OK" in which he compared homosexuality with bestiality.

77 Agriforum v Malema 20105 SA 235 (GNP); and see also Freedom Front $v$ South African Human Rights Commission 200311 BCLR 1283 (SAJRC).

78 Harmse $v$ Vawda (African National Congress Intervening) 11174/10 2011 ZAGPJHC 39 (16 May 2011) para 136.

79 Schabas 1999 AJIL 530.

80 Prosecutor $v$ Jean Kambanda, Case No ICTR-97-23-S (4 Sep 1998) para 39(x); and see also Prosecutor $v$ Georges Ruggia, Case No ICTR-97-32-1 (1 Jun 2000) para 44 (the accused pleading guilty of incitement to commit genocide for using phrases such as "go to work" in a public radio broadcast which came to mean 'go kill the Tutsis and Hutu political opponents of the interim government').

81 Du Toit v Minister of Safety and Security 20096 SA 128 (CC) para 28. 
South Africans when words were used that were common during the struggle days, but may be experienced as harmful by fellow inhabitants of South Africa today." 82 


\section{Bibliography}

Berat 1990 Emory Int'I L Rev

Berat $L$ "The Evolution of Self-determination in International Law: South Africa and Namibia, and the Case of Walvis Bay" 1990 Emory Int'l L Rev 251-290

Berman 1998 Wisc Int'l LJ

Berman N "Sovereignty in Abeyance: Self-determination and International Law" 1998 Wisc Int'l LJ 51-105

Booysen Volkereg

Booysen H Volkereg: 'n Inleiding (Juta Cape Town 1980)

Buchheit Secession

Buchheit L Secession: The Legitimacy of Self-Determination (Yale University Press New Haven 1978)

Cassese International Law

Cassese A International Law in a Divided World (Clarendon Press Oxford 1986)

Cassese Self-determination

Cassese A Self-determination of Peoples: A Legal Reappraisal (Cambridge University Press New York 1995)

Crawford Creation of States

Crawford $\mathrm{J}$ The Creation of States in International Law (Clarendon Press Oxford 1979)

Dinstein 1976 ILQ

Dinstein $Y$ "Collective Human Rights of Peoples and Minorities" 1976 ILQ 102-120 
Doehring "State"

Doehring K "State" in Bernhardt R (ed) Encyclopedia of Public International Law (Oxford University Press Oxford 1987) Vol X

Dooyeweerd New Critique

Dooyeweerd H A New Critique of Theoretical Thought (Padeia Press Jordan Station, Ontario 1969)

Dugard Recognition and the United Nations

Dugard J Recognition and the United Nations (Grotius Publishing Cambridge 1987)

Emerson 1971 AJIL

Emerson R "Self-Determination" 1971 AJIL 459-475

Ermacora 1983-IV Recueil des Cours

Ermacora F "The Protection of Minorities before the United Nations" 1983-IV

Recueil des Cours 246-370

Friedlander 1975 Detroit Col L Rev

Friedlander R "Self-determination: A Legal-Political Inquiry" 1975 Detroit Col L Rev 71-92

Heunis United Nations

Heunis J United Nations versus South Africa (Lex Patria Johannesburg 1986)

Higgins Development of International Law

Higgins R The Development of International Law Through the Political Organs of the United Nations (Oxford University Press London 1963)

Mosler "Subjects of International Law"

Mosler H "Subjects of International Law" in Bernhardt R (ed) Encyclopedia of Public International Law (Oxford University Press Oxford 1984) Vol VII 
Schabas 1999 AJIL

Schabas WA "Case Note" 93 AJIL 529-533

Schachter "United Nations and Internal Conflict"

Schachter O "The United Nations and Internal Conflict" in Moore JN (ed) Law and Civil War in the Modern World (John Hopkins Press Baltimore 1974) 401445

Tesfagiorgis 1987 Wisc Int'l LJ

Tesfagiorgis G "Self-determination: Its Evolution and Practice by the United Nations and Its Application in the Case of Eritrea" 1987 Wisc Int'I LJ 75-128

Van der Vyver 1991a Emory Int'l L Rev

Van der Vyver JD "Sovereignty and Human Rights in Constitutional and International law" 1991 Emory Int'l L Rev 321-443

Van der Vyver 1991b Emory Int'l L Rev

Van der Vyver JD "Statehood in International Law" 1991 Emory Int'l L Rev 9102

Van der Vyver "Constitutional Protection of Children"

Van der Vyver JD "Constitutional Protection of Children and Young Persons" in Robinson JA (ed) The Law of Children and Young Persons (Butterworths Durban 1997) 265-320

Van der Vyver 2000 J Transnat'l L \& Pol'y

Van der Vyver JD "Self-determination and the Peoples of Quebec" $2000 \mathrm{~J}$ Transnat'l L \& Pol'y 1-37

Van der Vyver "Self-determination"

Van der Vyver JD "Self-determination and the Right to Secession of Religious Minorities under International Law" in Dachin PG and Cole EA (eds) Protecting the Human Rights of Religious Minorities in Eastern Europe (Columbia University Press New York 2002) 251-293 
Van der Vyver 2003 Stell L Rev

Van der Vyver JD "Cultural Identity as a Constitutional Right in South Africa" 2003 Stell L Rev 51-67

Van der Vyver 2005 Emory Int'l L Rev

Van der Vyver JD "Limitations of Freedom of Religion or Belief: International Law Perspectives" 2005 Emory Int'l L Rev 499-537

Van Dyke Human Rights

Van Dyke V Human Rights, the United States, and World Community (Oxford University Press New York 1970)

Wilson "Fourteen Points Address"

Wilson W "Fourteen Points Address Delivered on January 8, 1918 to a Joint Session of Congress" in Baker RS and Dodd WE (eds) Public Papers of Woodrow Wilson: War and Peace Vol I (Harper \& Bros New York 1927) 155159

Wilson "War Aims"

Wilson W "War Aims of Germany and Austria - Address to Congress (11 Feb 1918)" in Richardson JD (ed) A Compilation of the Messages and Papers of the Presidents (New York, Bureau of National Literature, Inc.) Vol XVIII 84478450

\section{Register of court cases}

Aaland Islands Question 1920 League of Nations Official Journal (Supp 3)

Accordance with International Law of the Unilateral Declaration of Independence in respect of Kosovo ICJ General List No 141 (22 Jul 2010)

Agriforum v Malema 20105 SA 235 (GNP)

Dikoko v Mokhatla 20066 SA 235 (CC)

Du Plessis v De Klerk 19965 SA 658 (CC)

Du Toit v Minister for Safety and Security 20096 SA 128 (CC) 
Freedom Front $v$ South African Human Rights Commission 200311 BCLR 1283 (SAHRC)

Handyside $v$ The United Kingdom 19761 EHRRR 737

Harmse v Vawda (African National Congress Intervening) 11174/10 2011 ZAGPJHC

39 (16 May 2011)

Islamic Unity Convention v Independent Broadcasting Authority 20024 SA 295 (CC)

Jamait-Ul-Ulama of Transvaal $v$ Johncom Media Investment Ltd 1127/06 2006

ZAGPHC 12 (3 Feb 2006)

Legal Consequences for States of the Continued Presence of South Africa in

Namibia (South West Africa) Notwithstanding Security Council Resolution 276

(1970) (Advisory Opinion of 21 June 1971) 1971 ICJ 16

Masetlha $v$ President of the RSA 20081 SA 566 (CC)

P Johnson v 94.7 Highveld Stereo Case No 07/2002 Broadcasting Complaints Commission (14 Feb 2002)

Prosecutor v Georges Ruggia Case No ICTR-97-32-1 (1 Jun 2000)

Prosecutor v Jean Kambanda Case No ICTR-97-23-S (4 Sep 1998)

Reference Re Secession of Quebec 19982 SCR 217

$S$ v Makwanyane 19953 SA 391 (CC)

S v Mamabolo (E TV 7 others Intervening) 20013 SA 409 (CC)

South African Human Rights Commission v Jon Qwulane Case No 44/EQ JHB (31 May 2011)

Western Sahara (Advisory Opinion of 22 May 1975) 1975 ICJ 1

Woodways CC v Moosa Vallie Case No A251/05 (HC Western Cape) (31 Aug 2009)

\section{Register of legislation}

Commission for the Promotion and Protection of the Rights of Cultural, Religious and Linguistic Communities Act 19 of 2002

Constitution of the Federal Republic of Nigeria (1999)

Constitution of the Federal People's Republic of Yugoslavia (1946)

Constitution of the Federal People's Republic of Yugoslavia (1963)

Constitution of the Socialist Federal Republic of Yugoslavia (1974)

Constitution of the Republic of South Africa, 1996

Konstitutsiya SSSR (USSR Constitution) 1977 
Promotion of Equality and Prevention of Unfair Discrimination Act 4 of 2000

\section{Register of international instruments}

Charter of the Organisation of African Unity (1963)

Covenant on Civil and Political Rights (1966)

Covenant on Economic, Social and Cultural Rights (1966)

Declaration on the Elimination of Violence against Women (1993)

Declaration on the Granting of Independence to Colonial Countries and Peoples (1960)

Declaration on the Inadmissibility of Intervention in the Domestic Affairs of States and the Protection of Their Independence and Sovereignty (1965)

Declaration on Principles of International Law concerning Friendly Relations and CoOperation among States in accordance with the Charter of the United Nations (1970)

Declaration on the Rights of Indigenous Peoples (2007)

Declaration on the Rights of Persons Belonging to National or Ethnic, Religious and Linguistic Minorities (1992)

European Charter for Regional Minority Languages (1992)

European Framework Convention for the Protection of National Minorities (1995)

Final Act of the Conference on Security and Co-operation in Europe (1975)

Resolution adopted by the Assembly of Heads of State and Government, Cairo (1964)

Vienna Declaration and Programme of Action (1993)

\section{List of abbreviations}
AJIL
American Journal of International Law
Emory Int'I L Rev
Detroit Col L Rev
J Transnat'I L \& Pol'y
Emory International Law Review
Detroit College of Law Review
Journal of Transnational Law and Policy
ILQ
International Law Quarterly
Stell L Rev
Stellenbosch Law Review
Wisc Int'I LJ
Wisconsin International Law Journal 